\title{
ASSESSMENT OF PERFORMANCES OF YIELD AND FACTORS AFFECTING THE YIELD IN SOME SOYBEAN VARIETIES/LINES GROWN UNDER SEMI-ARID CLIMATE CONDITIONS
}

\author{
ARSLAN, H. ${ }^{*}-$ KARAKUŞ, M. $^{2}-$ HATIPOĞLU, H. $^{2}-$ ARSLAN, D. ${ }^{1}-$ BAYRAKTAR, Ö. V. ${ }^{3}$ \\ ${ }^{\text {I}}$ Field Crops Department, Faculty of Agriculture, Siirt University, Siirt, Turkey \\ ${ }^{2}$ Field Crops Department, GAP Agricultural Research Institute, Şanliurfa, Turkey \\ ${ }^{3}$ Agricultural Economy Department, Faculty of Agriculture, Siirt University, Siirt, Turkey \\ *Corresponding author \\ e-mail: huarslan@siirt.edu.tr \\ (Received 22 ${ }^{\text {nd }}$ Mar 2018; accepted 25 ${ }^{\text {th }}$ May 2018)
}

\begin{abstract}
The aim of this study was to determine the performances of yield and factors affecting the yield of 9 soybean lines and 2 standard soybean varieties grown in the soybean production seasons of 2012 and 2013 under semi-arid climatic conditions. The results indicated that performances of yield and other characteristics of soybean varieties/lines obtained in both trial seasons were significantly different from each other. The average temperature of experimental site in the first plant growing season was higher than that of the second year. The difference in temperatures between two growing seasons adversely influenced the yield, parameters affecting the yield and some quality parameters. Negative relationship between soybean yield and the temperature, an environmental factor that cannot be controlled during the growing season of the soybean, was obtained.
\end{abstract}

Keywords: soybean, heat stress, plant and environment interactions

\section{Introduction}

Soybean (Glycine max) is an important industrial legume as human and animal feed in the world with an average of $18-22 \%$ oil, 38-56\% vegetable protein in its seeds. Soybean is the most widely grown oilseed in the world as a main or second crop (USDA, 2018). The annual plant of soybean is a vertically branching plant and has pile root system that allows the use of water and nutrition in deeper soil profile (Baydar and Erbaş, 2014). Soybean that has a symbiosis with a special Rhizobium japonicum bacteria, is an extremely important plant in terms of improving the physical and chemical quality of soils. Soybean is consumed as soybean oil and soybean flour in human nutrition as well as in preparation of human foods such as dough products, baby foods, confectionery products, non-allergic milk and dairy products, special dietary products, artificial meat products and dry/cold instant (Öner, 2006). Soybean is used in many other sectors as in producing insecticides. Wax, soap, oil lamps, biodiesel, glue, paper raincoats and plastic materials are also produced using soybean. Soybean pulp contains $40-46 \%$ protein, $1-6 \%$ oil, $30-31 \%$ carbohydrates and $5-6 \%$ cellulose, thus is utilized as a good source of protein and fiber in livestock feeding (Singh and Shivakumar, 2010). Since soybean is extensively used in human nutrition, numerous researches have been conducted to determine the effects of soybean products on human health. The results revealed that individuals fed by soybean and soy products have a reduced risk of developing different types of cancers and soybean has a protective effect against cancers and also has positive effect in prevention of many other diseases 
(menopause, cholesterol, osteoporosis, cardiovascular and chronic diseases-coronary heart diseases) (Uesugi et al., 2013; Lovati et al., 1987; Messina, 1999; Xiao, 2008; Brouns, 2002).

Soybean is originated from China. Domestication and cultivation of soybean by humans in China dates from about the $11^{\text {th }}$ century BC or a little earlier according to oldest records (Hymowitz and Shurtleff, 2005). Soybean is introduced from the ancient world to the new world in the middle of $17^{\text {th }}$ century and gained its worldwide importance at the beginning of the $20^{\text {th }}$ century. The arrival to Turkey coincides with World War I (Arığlu, 2007).

The soybean planted area in the world 2016 was estimated at 121 million hectares and soybean production was 335 million tons (www.fao.org). The consumption of soybean per person is $40.64 \mathrm{~kg}_{\text {year }}{ }^{-1}$ based on the assumption that the entire soybean production in the world is consumed by humans. But a large part of the produced soybean is used in animal feeding. Soybean is suitable for growing in both temperate and tropical climates with diverse environmental conditions (Hasanuzzaman et al., 2016). However, soybean production in Turkey is only 150 thousand tons in 34 thousand hectares. Despite the appropriate climate, soil and water resources to produce higher amounts in Turkey and the importance of soybean in human and animal nutrition as well as a raw material in industry, Turkey imports significant amount of soybean and processed soy products. Soybean is ranked $4^{\text {th }}$ in Turkey among the imported agricultural products with 1,073,757 tons and ranked 3rd with 1.08674 million tons as processed soybean (www.fao.org). For this reason, studies on the cultivation and adaptation of soybean varieties are of great importance to increase the soybean production in the country.

Abiotic stress or extreme environmental conditions such as soil salinity, long term drought, low and high temperatures, nutrient deficiency or toxicity of heavy metals etc. may cause significant reduction in quality traits and yield of soybean varieties (Jumrani and Bhatia, 2018; Shah and Paulsen, 2003; Hasanuzzaman et al., 2016). Also many researchers have examined the effects of environmental factors on yield and quality. It has been shown that environmental factors significantly affect yield and quality in soybean cultivation (Piper and Boote, 1999; Thomas et al., 2003; Kumar et al., 2003; Pipolo et al., 2004). This study was carried out in semi-arid climatic conditions to determine oil and protein ratios of soybean seeds, yield and factors influencing the yield in different soybean genotypes.

\section{Material and method}

The study was conducted during the main soybean crop production season in 2012 and 2013. In the study, 2 standard soybean varieties (Ataem-7 and Türksoy) and 9 advanced soybean lines $(6,11,17,24,27,834,1021$ and 1022) were used as material. Standard varieties used as materials in the experiment were used because they conformed to the local conditions. The lines used in this study were the crossbreeds of the parents shown in Table 1 and were obtained in 1999.

The field experiments were carried out in the Gündaş research station of GAP Agricultural Research Institute during soybean growing seasons in 2012 and 2013. The Gündaş station is located at 360 44' $05.22 \mathrm{~N}$ and $38048^{\prime} 49.76 \mathrm{E}$ within the borders of Akçakale town of Sanliurfa province, Turkey (Fig. 1). The summers are dry and hot, and the winters are relatively warm. The average temperature in July and August is 


$$
-4291-
$$

$40{ }^{\circ} \mathrm{C}$, while during some nights the temperature goes above $30{ }^{\circ} \mathrm{C}$ (https://mevbis.mgm.gov.tr, 2017).

Table 1. Pedigrees of lines

\begin{tabular}{c|c|c}
\hline Line number & o & + \\
\hline 6 & Wayne & Keller \\
11 & Spancer & SGI 1308 \\
13 & Williams & Keller \\
17 & Spancer & SGI 1308 \\
24 & Williams & Keller \\
27 & Williams & Keller \\
834 & Williams & Keller \\
1021 & Spancer & SGI 1308 \\
1022 & Spancer & SGI 1308 \\
\hline
\end{tabular}

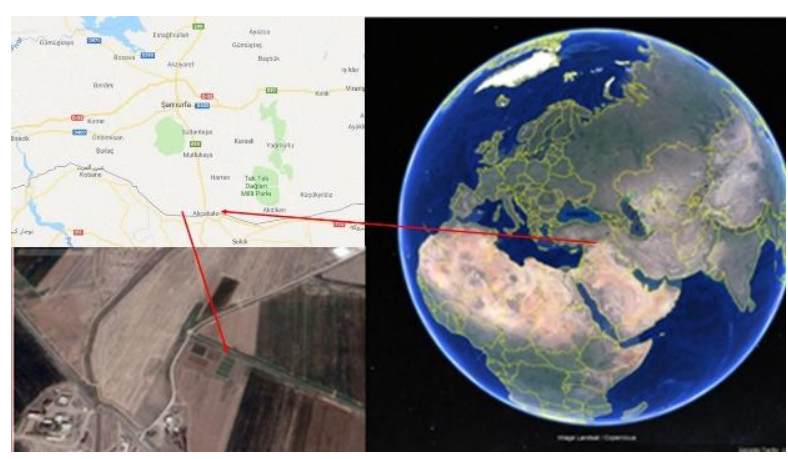

Figure 1. The area of trial

Some physical and chemical characteristics of the soil samples taken from the experimental fields are given in Table 2. The experimental fields were similar in terms of soil water saturation (\%), soil $\mathrm{pH}$ level, soil salinity $\left(\mathrm{EC} \mathrm{ds} \mathrm{m}^{-1}\right)$, calcium carbonate $(\%)$, plant available phosphorus $\left(\mathrm{P}_{2} \mathrm{O}_{5}, \mathrm{~kg} \mathrm{ha}^{-1}\right)$, potassium $\left(\mathrm{K}_{2} \mathrm{O}, \mathrm{kg} \mathrm{ha}^{-1}\right)$ and soil organic matter content (Table 2).

Table 2. Soil properties of trial areas

\begin{tabular}{c|c|c|c|c|c|c|c}
\hline Years & $\begin{array}{c}\text { Water } \\
\text { saturation } \\
\text { rate (\%) }\end{array}$ & $\mathbf{p H}$ & $\mathbf{E c ~ d s / m}$ & $\begin{array}{c}\text { Lime } \\
\mathbf{R A T E} \\
(\boldsymbol{\%})\end{array}$ & $\begin{array}{c}\left.\mathbf{P h o s h o r u s}_{\mathbf{2}} \mathbf{O}_{\mathbf{5}} \mathbf{( k g ~ h a ~}^{-1}\right) \\
\mathbf{P o t a s s i u m ~ K}_{\mathbf{2}} \mathbf{O} \\
\left(\mathbf{k g ~ h a}^{-1}\right)\end{array}$ & $\begin{array}{c}\text { Organic } \\
\text { matter rate } \\
(\boldsymbol{\%})\end{array}$ \\
\hline 2012 & 64 & 7.53 & 0.51 & 26.6 & 56.0 & 2490 & 2.32 \\
2013 & 69 & 7.47 & 0.89 & 24.3 & 51.9 & 3000 & 2.45 \\
\hline
\end{tabular}

The meteorological data indicated that the temperatures in 2012 were generally higher than those of 2013. The average temperatures of June, July and August which are the vegetative and generative development periods of the soybean, was warmer in 2012 (Table 3). 
Table 3. The climate data of 2012, 2013 and the long terms averages of Akçakale Town (21)

\begin{tabular}{|c|c|c|c|c|c|c|}
\hline Months & Years & $\begin{array}{c}\text { Monthly } \\
\text { average min. } \\
\text { temp. }\left({ }^{\circ} \mathrm{C}\right)\end{array}$ & $\begin{array}{c}\text { Monthly } \\
\text { average max. } \\
\text { temp. }\left({ }^{\circ} \mathrm{C}\right)\end{array}$ & \begin{tabular}{|c|} 
Monthly \\
average \\
temp. $\left({ }^{\circ} \mathrm{C}\right)$
\end{tabular} & $\begin{array}{c}\text { Monthly } \\
\text { average relative } \\
\text { humidity }(\%)\end{array}$ & $\begin{array}{l}\text { Monthly total } \\
\text { precipitation } \\
\left(\mathrm{mm}=\mathrm{kg} \div \mathrm{m}^{2}\right)\end{array}$ \\
\hline \multirow{3}{*}{ April } & 2012 & 10.70 & 26.90 & 18.60 & 48.30 & 44.80 \\
\hline & 2013 & 10.10 & 26.00 & 17.80 & 53.00 & 9.20 \\
\hline & LTA $^{*}$ & 8.19 & 23.86 & 16.34 & 67.64 & 25.96 \\
\hline \multirow{3}{*}{ May } & 2012 & 14.60 & 29.80 & 22.00 & 49.80 & 43.20 \\
\hline & 2013 & 15.60 & 31.60 & 23.30 & 47.20 & 43.40 \\
\hline & LTA & 13.00 & 30.20 & 22.56 & 56.42 & 22.82 \\
\hline \multirow{3}{*}{ June } & 2012 & 20.80 & 38.20 & 30.10 & 26.00 & 4.60 \\
\hline & 2013 & 19.60 & 36.80 & 28.70 & 28.90 & 0.20 \\
\hline & LTA & 17.46 & 36.01 & 28.19 & 47.34 & 3.12 \\
\hline \multirow{3}{*}{ July } & 2012 & 23.10 & 40.40 & 32.10 & 26.30 & 0.00 \\
\hline & 2013 & 21.90 & 39.60 & 31.30 & 27.20 & 0.00 \\
\hline & LTA & 20.73 & 39.90 & 31.41 & 46.23 & 0.60 \\
\hline \multirow{3}{*}{ August } & 2012 & 21.90 & 39.80 & 31.10 & 32.70 & 0.00 \\
\hline & 2013 & 20.90 & 39.40 & 30.40 & 30.60 & 0.00 \\
\hline & LTA & 19.87 & 38.99 & 30.43 & 48.37 & 0.60 \\
\hline \multirow{3}{*}{ September } & 2012 & 17.80 & 36.30 & 26.80 & 37.80 & 3.80 \\
\hline & 2013 & 16.50 & 33.70 & 25.10 & 38.70 & 0.00 \\
\hline & LTA & 15.28 & 34.44 & 25.39 & 52.11 & 0.55 \\
\hline \multirow{3}{*}{ October } & 2012 & 14.10 & 28.40 & 20.80 & 54.80 & 35.20 \\
\hline & 2013 & 10.00 & 26.90 & 18.40 & 33.50 & 0.40 \\
\hline & LTA & 11.28 & 27.98 & 19.74 & 59.09 & 21.41 \\
\hline
\end{tabular}

*Long term average (1929-2017)

The experiments were established in a randomized block design with three replicates on May 08 and May 06 in 2012 and 2013, respectively. Each plot was $6 \mathrm{~m}$ long and plants were grown in 4 rows with a $70-\mathrm{cm}$ row and a $5-\mathrm{cm}$ inter-plant (intra row) spacing. Irrigation, hoeing, and all other cultural practices have been uniformly applied to all the experimental plots to minimize the experimental error. Plants were harvested between 01 and 11, October in 2012, and 05 and 10, October in 2013. Rhizobium japonicum bacterial inoculation was not carried out during planting. Data were recorded for grain yield $\left(\mathrm{kg} \mathrm{ha}^{-1}\right)$, plant height, first pod height, number of pods per plant, 1000grain weight. Seed oil and protein ratios which are important quality characteristics were also determined.

The data were subjected to analyses of variance using JMP (JMP is a division of SAS that produces interactive statistical discovery software) statistic software package and average values for each of the traits were grouped according to LSD test.

\section{Results}

The mean values of properties examined for varieties/lines used as materials in the experiment and the groups obtained for the values of 2012 are presented in Table 4. 
Table 4. Mean values and groups of the investigated characteristics of different soybean varieties/lines at 2012-2013 growing seasons

\begin{tabular}{|c|c|c|c|c|c|c|c|c|c|c|c|c|c|c|}
\hline Years & $\begin{array}{l}\text { Varieties } \\
\text { /lines }\end{array}$ & \multicolumn{2}{|c|}{$\begin{array}{l}\text { Yield }^{* *} \\
\left(\text { kg ha }^{-1}\right)\end{array}$} & \multicolumn{2}{|c|}{$\begin{array}{c}\text { Plant height } \\
\text { (cm) }\end{array}$} & \multicolumn{2}{|c|}{$\begin{array}{c}\text { First pod } \\
\text { height }(\mathrm{cm})\end{array}$} & \multicolumn{2}{|c|}{\begin{tabular}{|c|}
$\begin{array}{c}\text { Number } \\
\text { of pod per } \\
\text { plant }\end{array}$ \\
\end{tabular}} & \multicolumn{2}{|c|}{$\begin{array}{c}\text { Weight of } \\
1000 \\
\text { grain }(g)\end{array}$} & \multicolumn{2}{|c|}{$\begin{array}{l}\text { Oil rate } \\
\quad(\%)\end{array}$} & $\begin{array}{c}\text { Protein } \\
\text { rate }(\%)\end{array}$ \\
\hline \multirow{15}{*}{2012} & 11 & 2950.00 & $\mathrm{a}$ & \multirow{2}{*}{\multicolumn{2}{|c|}{$\begin{array}{l}121.33 \\
125.00\end{array}$}} & \multicolumn{2}{|c|}{24.17} & \multicolumn{2}{|c|}{50.53} & 185.33 & $\mathrm{~b}$ & \multicolumn{2}{|l|}{15.89} & 36.97 \\
\hline & Ataem-7 & 2900.50 & $\mathrm{a}$ & & & \multicolumn{2}{|c|}{23.77} & \multicolumn{2}{|c|}{55.67} & 165.33 & $b c$ & \multicolumn{2}{|l|}{15.83} & 35.68 \\
\hline & 13 & 2760.50 & $\mathrm{a}$ & \multicolumn{2}{|c|}{119.77} & \multicolumn{2}{|c|}{18.50} & \multicolumn{2}{|c|}{53.77} & 181.33 & $\mathrm{~b}$ & \multicolumn{2}{|l|}{15.44} & 37.46 \\
\hline & 834 & 2560.50 & $\mathrm{~b}$ & \multicolumn{2}{|c|}{119.77} & \multicolumn{2}{|c|}{18.77} & \multicolumn{2}{|c|}{44.67} & 178.67 & $b$ & \multicolumn{2}{|l|}{17.52} & 35.39 \\
\hline & 27 & 2552.90 & $\mathrm{~b}$ & \multicolumn{2}{|c|}{118.77} & \multicolumn{2}{|c|}{23.60} & \multicolumn{2}{|c|}{46.00} & 176.00 & $\mathrm{bc}$ & \multicolumn{2}{|l|}{18.00} & 34.56 \\
\hline & 17 & 2500.00 & $\mathrm{~b}$ & 110. & & 26 & & 47.8 & & 146.67 & $\mathrm{c}$ & 17.67 & & 36.48 \\
\hline & 1022 & 2433.30 & $\mathrm{~b}$ & 125. & & 24 & & 40.3 & & 222.67 & $\mathrm{a}$ & 18.18 & & 35.78 \\
\hline & 24 & 2413.80 & $\mathrm{~b}$ & 115. & & 23 & & 42.2 & & 173.33 & $\mathrm{bc}$ & 16.18 & & 34.73 \\
\hline & Türksoy & 2150.00 & $\mathrm{c}$ & 121. & & 28 & & 42.0 & & 172.67 & $\mathrm{bc}$ & 17.20 & & 35.28 \\
\hline & 1021 & 2145.70 & $\mathrm{c}$ & 124. & & 21 & & 43.5 & & 177.33 & $\mathrm{bc}$ & 16.85 & & 37.22 \\
\hline & 6 & 2044.30 & c & 122. & & 18 & & 45.2 & & 194.67 & $a b$ & 17.36 & & 37.00 \\
\hline & Average & 2492.00 & & 120. & & 22 & & 46.5 & & 179.45 & & 16.92 & & 36.05 \\
\hline & CV (\%) & 4.54 & & 5.8 & & 25 & & 14.4 & & 10.10 & & 7.09 & & 5.70 \\
\hline & LSD & 192.70 & & .I & & Ö. & & Ö.D & & 30.88 & & Ö.D. & & Ö.D. \\
\hline & $\begin{array}{c}\text { Varieties } \\
\text { /lines }\end{array}$ & $\begin{array}{c}\text { Yield" }^{*} \\
\text { (kg ha }^{-1}\end{array}$ & & $\begin{array}{r}\text { Plant h } \\
(\mathbf{c m}\end{array}$ & leight & $\begin{array}{r}\text { First } \\
\text { hei } \\
\text { (cr }\end{array}$ & & \begin{tabular}{|r|} 
Numl \\
of pod \\
plan
\end{tabular} & $\begin{array}{l}\text { ber } \\
\text { per } \\
t^{* *}\end{array}$ & $\begin{array}{r}\text { Weigh } \\
100 \\
\text { grain }\end{array}$ & & Oil rate & & $\begin{array}{l}\text { Protein } \\
\text { rate }(\%)\end{array}$ \\
\hline & 11 & \begin{tabular}{|l|}
4464.30 \\
\end{tabular} & $\mathrm{a}$ & 105.20 & $\mathrm{~cd}$ & 17.47 & bcd & 75.47 & $\mathrm{a}$ & 185.33 & $\mathrm{c}$ & 20.80 & $\mathrm{ab}$ & 35.60 \\
\hline & 13 & 4339.30 & $a b$ & 114.67 & $a b$ & 19.60 & $a b c$ & 71.27 & $a b$ & 180.33 & $\mathrm{~cd}$ & 18.49 & $\mathrm{c}$ & 37.43 \\
\hline & 27 & 4214.30 & $\mathrm{bc}$ & 116.47 & $\mathrm{a}$ & 16.00 & $\mathrm{~d}$ & 54.67 & de & 187.00 & $\mathrm{bc}$ & 21.21 & $a b$ & 35.61 \\
\hline & 1021 & 4071.40 & $\mathrm{~cd}$ & 104.13 & $\mathrm{~cd}$ & 19.87 & $a b c$ & 48.80 & ef & 196.00 & $b$ & 22.56 & a & 34.30 \\
\hline & Ataem-7 & 4000.00 & $\mathrm{~cd}$ & 111.20 & $a b c$ & 18.73 & abcd & 54.33 & de & 173.33 & de & 19.73 & $\mathrm{bc}$ & 37.15 \\
\hline & 1022 & 3982.10 & $\mathrm{~d}$ & 107.00 & bcd & 21.00 & $\mathrm{a}$ & 54.00 & e & 207.67 & $a$ & 21.87 & a & 35.31 \\
\hline & 834 & 3928.60 & $\mathrm{~d}$ & 100.93 & $\mathrm{~d}$ & 16.33 & $\mathrm{~d}$ & 42.73 & $\mathrm{f}$ & 163.33 & $\mathrm{e}$ & 21.13 & $a b$ & 35.27 \\
\hline & Türksoy & 3928.60 & $\mathrm{~d}$ & 108.60 & bcd & 20.00 & $a b$ & 48.73 & ef & 185.00 & $\mathrm{c}$ & 21.90 & a & 35.33 \\
\hline & 17 & 3875.00 & de & 114.47 & $a b$ & 21.07 & $\mathrm{a}$ & 62.40 & $\mathrm{~cd}$ & 172.67 & de & 20.80 & $a b$ & 35.03 \\
\hline & 6 & 3678.60 & $\mathrm{e}$ & 106.40 & $\mathrm{~cd}$ & 17.20 & bcd & 54.13 & $\mathrm{e}$ & 185.67 & $c$ & 21.Şub & $a b$ & 35.66 \\
\hline & 24 & 2892.90 & $\mathrm{f}$ & 102.53 & $d$ & 17.00 & $\mathrm{~cd}$ & 64.60 & $\mathrm{bc}$ & 182.00 & $\mathrm{~cd}$ & 19.46 & $\mathrm{bc}$ & 36.29 \\
\hline & Average & 3943.20 & & 108.32 & & 18.57 & & 57.38 & & 183.49 & & 20.82 & & 35.73 \\
\hline & CV (\%) & 3.38 & & 4.22 & & 9.08 & & 8.32 & & 3.25 & & 5.08 & & 4.81 \\
\hline & LSD & 22.70 & & 7.79 & & 2.87 & & 8.13 & & 10.15 & & 1.80 & & Ö.D. \\
\hline
\end{tabular}

The grain yields $\left(\mathrm{kg} \mathrm{ha}^{-1}\right)$ for different soybean varieties/lines were statistically significant at $\mathrm{p}<0.01$ level and the 1000-grain weight significant at $\mathrm{p}<0.05$ level. However, the values for plant height, the first pod height, the number of pods per plant, the oil and protein ratio among the different soybean varieties/lines were not statistically different. The yield of varieties / lines ranged from 2044.30 to $2950.00 \mathrm{~kg}$ $\mathrm{ha}^{-1}$. The highest yield was obtained as $2950.00 \mathrm{~kg} \mathrm{ha}^{-1}$ with the line 11 , while the lowest yield was obtained as $2044.30 \mathrm{~kg} \mathrm{ha}^{-1}$ with line 6 . The plant height of varieties/lines varied between 110.27 and $125.70 \mathrm{~cm}$. The highest plant height was 
$125.70 \mathrm{~cm}$ with line 1022, while the lowest plant height was $110.27 \mathrm{~cm}$ with line 17 . The first pod height values ranged from 18.00 (Türksoy variety) to $28.77 \mathrm{~cm}$ (line 6). The highest number was obtained from the Türksoy variety $(28.77 \mathrm{~cm})$ and the lowest value was obtained from the line $6(18.00 \mathrm{~cm})$. The highest value number of pods per plant was obtained from Ataem-7 as 55.67 pods/plant, and the lowest value was obtained from line 1022 as 40.37 pods/plant. The highest 1000-grain weight (222.67 g) was occurred with line 1022 and the lowest weight $(146.67 \mathrm{~g})$ was obtained with line 17. The oil rate values of varieties/lines varied between 15.44 and $18.18 \%$. The highest oil ratio $(18.18 \%)$ was found in line 1022 , while the lowest oil ratio $(15.44 \%)$ in line 13 . The highest protein ratio $(37.46 \%)$ was obtained with line 13 and the lowest protein ratio $(34.73 \%)$ in line 24.

The mean values of properties examined and the groups obtained for varieties/lines 2012 are presented in Table 4 . The values of grain yield $\left(\mathrm{kg} \mathrm{ha}^{-1}\right)$, plant height $(\mathrm{cm})$, number of pods per plant (pod plant ${ }^{-1}$ ) and 1000-grain weight $(\mathrm{g})$, and oil ratio (\%) were significantly different $(\mathrm{p}<0.01)$ among the different soybean varieties/lines. The difference in the first pod height was significant at $\mathrm{p}<0.05$ level. The differences in protein values among varieties/lines were not statistically significant in 2013 . The grain yield of varieties/lines was ranged from 2892.90 (line 24) to $4464.30 \mathrm{~kg} \mathrm{ha}^{-1}$ (line 11). The plant height of varieties/lines was between $100.93 \mathrm{~cm}$ (line 834) and $116.47 \mathrm{~cm}$ (line 27). The highest first pod height value $(21.07 \mathrm{~cm}$ ) was obtained for line 17 , while the lowest value $(16.00 \mathrm{~cm})$ was occurred with line 27 . Line 11 yielded the highest number of pods per plant (75.47) whereas the lowest number of pods per plant was obtained for line 834 as 42.73 pods plant ${ }^{-1}$. The highest 1000 -grain weight $(207.67 \mathrm{~g})$ was found with line 1022 and the lowest 1000-grain weight (163.33 g) was obtained with line 834 . The oil rate among varieties/lines was ranged from $18.49 \%$ (line 13) to $22.56 \%$ (line 1021). The highest protein content was obtained with line 13 (37.43\%) and the lowest was in line $1021(34.30 \%)$.

\section{Discussion}

In the second year of the experiment, grain yields and oil ratios of all varieties/lines were higher, whereas plant lengths were lower compared to the first year of the study. The first pod height values of varieties were lower except for line 13 which was significantly higher than in the first year of the experiment. The number of pod per plant in the second season was lower in Ataem-7 variety and line 834 compared to the first growing season of the study. The 1000-grain weights of lines 13, 834, 1022 and 6 in 2012 were lower compared to the second year, while it was similar for line 11, and higher for Ataem-7 and Türksoy varieties and lines of 27, 17, 24 and 1021. The protein ratios of Türksoy and Ataem-7 varieties and 27 and 24 lines increased in the second year and decreased in other varieties/lines.

\section{Grain yield}

The average soybean yield in $2012\left(249.20 \mathrm{~kg} \mathrm{da}^{-1}\right)$ was lower than that of 2013 (394.32 $\mathrm{kg} \mathrm{da}^{-1}$ ). The average, maximum, minimum and total temperatures during the growing season of 2012 (June, July, August) were higher than those of 2013 (Table 3). Higher temperatures during the vegetative and generative periods in 2012 compared to those of 2013 resulted in lower grain yields of varieties/lines in 2012. Increasing temperature causes water stress (Jumrani and Bhatia, 2018; Pipolo et al., 2004; Shah 
and Paulsen, 2003) which negatively affects the fertilization of the flowers, and also causes flowers to fall down. Eventually, significant losses occur in grain yield of crops (Dornbos and Mullen, 1992).

\section{Relationship between grain yield and yield components}

A correlation test was conducted to determine the relationship between the grain yield and the factors affecting the yield of soybean varieties/lines (Tables 5 and 6). Although not statistically significant in the first year, there was a negative correlation between the grain yield and plant height, the 1000-grain weight, the oil ratio and the protein ratio, and a positive relationship between yield and the first pod height. However, a statistically significant positive correlation was found between yield and number of plant pods. In the second year, a statistically non-significant positive relationship was found between the grain yield and the plant height, the first pod height, the number of pods per plant, the 1000-grain weight, the oil ratio and the protein ratio. The positive correlations between grain yield and the first pod height and the pod number per plant revealed that increases in the first pod height and the number of plant pods resulted in considerable increases in grain yields. The height of first pod and the number of pods per plant are important factors positively affecting the yield and both have been considerably changed with variation in temperature between the experimental years (Table 7). Due to the higher temperatures, the first pod height was higher in the first year compared to that in the second year.

Table 5. Correlation coefficients between the inspected features, 2012

\begin{tabular}{c|c|c|c|c|c|c}
\hline & Yield & $\begin{array}{c}\text { Plant } \\
\text { height }\end{array}$ & $\begin{array}{c}\text { First pod } \\
\text { height }\end{array}$ & $\begin{array}{c}\text { Number of pod } \\
\text { per plant }\end{array}$ & $\begin{array}{c}\text { Weight of } \\
\text { 1000 grain }\end{array}$ & Oil rate \\
\hline Plant height & -.045 & & & & & \\
First pod height & .101 & .118 & & & & \\
Number of pod per plant & $.499^{* *}$ & -.214 & -.203 & & & \\
Weight of 1000 grain & -.065 & .093 & -.094 & .089 & & \\
Oil rate & -.327 & -.017 & .087 & $-.365^{*}$ & -.014 & \\
Protein rate & -.094 & -.021 & -.158 & .227 & .253 & $-.364^{*}$ \\
\hline
\end{tabular}

*Correlation is significant at the 0.05 level (2-tailed)

**Correlation is significant at the 0.01 level (2-tailed)

Table 6. Correlation coefficients between the inspected features, 2013

\begin{tabular}{c|c|c|c|c|c|c}
\hline & Yield & $\begin{array}{c}\text { Plant } \\
\text { height }\end{array}$ & $\begin{array}{c}\text { First pod } \\
\text { height }\end{array}$ & $\begin{array}{c}\text { Number of } \\
\text { pod per plant }\end{array}$ & $\begin{array}{c}\text { Weight of } \\
\text { 1000 grain }\end{array}$ & Oil rate \\
\hline Plant height & .281 & & & & & \\
First pod height & .185 & .069 & & & & \\
Number of pod per plant & .155 & .252 & -.037 & & & \\
Weight of 1000 GRAİN & .095 & -.284 & .249 & .008 & & \\
Oil rate & .076 & .021 & .095 & $-.446 * *$ & .154 & \\
Protein rate & .051 & $-.389^{*}$ & .144 & .027 & .290 & $-.552^{* * *}$ \\
\hline
\end{tabular}

*Correlation is significant at the 0.05 level (2-tailed)

**Correlation is significant at the 0.01 level (2-tailed) 
Table 7. Correlation coefficients between two years temperature differences and the inspected features

\begin{tabular}{|c|c|c|c|c|c|c|c|}
\hline & Year & Yield & \begin{tabular}{|c|} 
Plant \\
height
\end{tabular} & $\begin{array}{c}\text { First pod } \\
\text { height }\end{array}$ & \begin{tabular}{|c|}
$\begin{array}{c}\text { Number of } \\
\text { pod per plant }\end{array}$ \\
\end{tabular} & $\begin{array}{c}\text { Weight of } \\
1000 \text { grain }\end{array}$ & Oil rate \\
\hline Yield & $-.896 * *$ & & & & & & \\
\hline Plant height & $.620 * *$ & $-.511 * *$ & & & & & \\
\hline First pod height & $.447 * *$ & $-.356^{* *}$ & $.347 * *$ & & & & \\
\hline Number of pod per plant & $-.514 * *$ & $.566^{* *}$ & $-.293 *$ & $-.324 * *$ & & & \\
\hline Weight of 1000 grain & -.106 & .097 & -.092 & -.073 & .096 & & \\
\hline Oil rate & $-.816^{* *}$ & $.710^{* *}$ & $-.506^{* *}$ & $-.323 * *$ & .216 & .115 & \\
\hline Protein rate & .069 & -.061 & -.129 & -.006 & .047 & .237 & $-.330 * *$ \\
\hline
\end{tabular}

Despite the decreasing number of pods per plant compared to the second year due to the high temperature, the grain size remained unchanged and therefore the 1000-grain weight was not significantly decreased compared to the first year. Higher temperatures in the first year caused decline in the number of grains per pod and this had a negative impact on grain yield. A negative correlation between the 1000-grain weight and the grain yield may actually be attributed to the decline in the number of grains per pod. In summary, a decrease in the number of grains per pod in the first year resulted an increase of the 1000-grain weight, while an increase in the number of the grains per pod caused a lower the 1000-grain weight. Also Ionescu et al. (2016) has reported that the relationship between the number of capsules in the plant and the 1000-grain weight is negative. Therefore, the grain yield depending on the number of the pod per plant is assumed to have a negative relationship with the weight of the 1000 grain.

\section{Oil and protein ratio (\%)}

Environmental factors as well as genetic characteristics of genotypes are also effective in influencing the chemical content of soybean (Jumrani and Bhatia, 2018; Shah and Paulsen, 2003). The oil and protein ratios of the soybean are as important as the grain yield. The oil and protein ratios of both years are given in Table 4. The oil ratio of varieties/lines were between 15.44 and $18.18 \%$ in the first year and it was between 18.49 and $22.56 \%$ in the second year (Table 4). Similar to the oil ratio, the grain yield was also lower in 2012 compared to that in 2013. Differences in oil ratios of genotypes between two growing seasons are related to responses of genotypes to environmental factors. Some researchers have reported similar results (Piper and Boote, 1999 and Wang, et al., 2015). In other words, the high temperatures during the growing season in 2012 caused the oil ratio of grains to significantly decrease in parallel with the grain yield. The difference between the average protein ratios of the two years is not significant, though the protein ratio of the first year is relatively higher than that of the second year. Also, Kumar et al. (2006) has similarly found that the mean air temperature during bean development showed a significant positive correlation with protein and a negative correlation with oil. The results revealed that the protein ratio of the grain does not react to the temperature as in the grain yield and the oil ratio of the grain (Table 7). The correlation test showed that the oil and protein ratios of the soybean grains had significant negative relationships $(\mathrm{p}<0.05$ and $\mathrm{p}<0.01$ in the first 
and second years, respectively). Similar to our findings, Johnson et al. (1955) also reported a significant negative relationship between oil and protein rates of soybean grains.

\section{Conclusion}

A two-year field experiment (2012-2013) was conducted to determine the performances of two standard soybean varieties and 11 soybean lines under semi-arid climate conditions by evaluating the yield, factors affecting the yield and some quality traits. Performance of yield and other characteristics of soybean varieties/lines differed between two growing seasons. The average temperature of the study area during the growing season in the first year was higher than that of the second year. The higher temperature in the first growing season had a negative impact on the yield, the factors affecting the soybean yield and the oil ratio of the soybean grain. A negative relationship between oil ratio and protein ratio of the soybean grains is one of the most important findings of the study. In conclusion, the yields of soybean varieties/genotypes have been negatively affected by the extreme temperature, one of the most important environmental factors.

Acknowledgements. This study was conducted by the supports of General Directorate of Agricultural Research and Politics affiliated to the Turkish Republic Ministry of Food, Agriculture and Livestock within the scope of Soybean Breeding Project (TAGEM/TA/09/05/01/0014). Soybean line 11 was registered as GAPSOY-16 in 2016 by the Directorate of Seed Registration and Certification Center affiliated to the Ministry of Food, Agriculture and Livestock of Turkey.

\section{REFERENCES}

[1] Arioğlu, H. H. (2007): Oil Crops Production and Breeding, Textbooks (in Turkish). Publication No: A-70, Çukurova University, Offset Atelier of Faculty of Agriculture, Adana/Turkey, pp. 14-21, 49.

[2] Baydar, H., Erbaş, S. (2014): Oil Resources Science and Technology Course Book (in Turkish). - Süleyman Demirel University, Faculty of Agriculture, Isparta/Turkey.

[3] Brouns, F. (2002): Soya isoflavones: a new and promising ingredient for the health foods sector. - Food Research International 35(2): 187-193.

[4] Dornbos, D. L. Jr., Mullen, R. E. (1992): Soybean seed protein and oil contents and fatty acid composition adjustments by drought and temperature. - Journal of the American Oil Chemists Society 69(3): 228-231.

[5] Food and Agriculture Organization (2017): User's Guide: Statistics. http://www.fao.org/faostat/en/\#data/QC (accessed on 08.08.2017).

[6] Hasanuzzaman, M., Nahar, K., Rahman, A., Mahmud, J. A., Hossain, M. S., Fujita, M. (2016): Soybean production and environmental stresses. - Environmental Stresses in Soybean Production 2: 61-102.

[7] Hymowitz, T. Shurtleff, W. R. (2005): Debunking soybean myths and legends in the historical and popular literature. - Crop Science 45(2): 473-476.

[8] Ionescu, N., Penescu, A., Chirlă, P. (2016): Ecology issues of soybean crop plants. Agrolife Scientific Journal 5(1): 99-104.

[9] Johnson, H. W.; Robinson, H. F.; Comstock, R. E. (1955): Genotypic and phenotypic correlations in soybeans and their implications in selection. - Agronomy Journal Madison 47: 477-483. 
[10] Jumrani K, Bhatia V. S. (2018): Impact of combined stress of high temperature and water deficit on growth and seed yield of soybean. - Physiol Mol Biol Plants 24(1): 37-50.

[11] Kumar, V., Rani, A., Tindwani, C., Jain, M. (2003): Lipoxygenase isozymes and trypsin inhibitor activities in soybean as influenced by growing location. - Food Chemistry 81: 79-83.

[12] Kumar, V., Rani, A., Solanki, S., Hussain, S. M. (2006): Influence of growing environment on the biochemical composition and physical characteristics of soybean seed. - J Food Compos Anal 19: 188-195.

[13] Lovati, M. R., Manzoni, C., Canavesi, A., Sirtori, M., Vaccarino, V., Marchi, M., Gaddi, G., Sirtori, C. R. (1987): Soybean protein diet increases low density lipoprotein receptor activity in mononuclear cells from hypercholesterolemic patients. - The Journal of Clinical Investigation 80(5): 1498-1502.

[14] Messina, M. J. (1999): Legumes and soybeans: overview of their nutritional profiles and health effects. - American Journal of Clinical Nutrition. 70(3 Suppl): 439S-450S.

[15] Öner, T. (2006): Soybean Industry Report, pp. 7-8. - http://www.ito.org.tr/ Dokuman/Sektor/1-84.pdf (accessed on 20/09/2016).

[16] Piper, E. L., Boote, K. I. (1999): Temperature and cultivar effects on soybean seed oil and protein concentration. - Journal of the American Oil Chemists' Society 76(10): 12331241.

[17] Pipolo, A. E., Sinclair, T. R., Camara, T. M. S. (2004): Effects of temperature on oil and protein concentration in soybean seeds cultured in vitro. - Annals of Applied Biology 144(1): 71-76.

[18] Shah, N. H., Paulsen, G. M. (2003): Interaction of drought and high temperature on photosynthesis and grain-filling of wheat. - Plant and Soil 257: 219-226.

[19] Singh, G., Shivakumar, B. G. (2010): The Role of Soybean in Agriculture. - In: Singh, B. (ed.) The Soybean: Botany, Production and Uses. CAB International, Oxfordshire, pp. 24-47.

[20] Thomas, J. M. G., Boote, K. J., Allen, L. H., Gallo-Meagher, M., Davis, J. M. (2003): Elevated temperature and carbon dioxide effects on soybean seed composition and transcript abundance. - Crop Science 43: 1548-1557.

[21] Turkish State Meteorological Service (2017): Meteorological Data Information Sales and Presentation System. - https://mevbis.mgm.gov.tr/mevbis/ ui/index.html\#/Workspace (accessed on 08.08.2017).

[22] Uesugi, T., Fukui, Y., Yamori, Y. (2013): Beneficial effects of soybean isoflavone supplementation on bone metabolism and serum lipids in postmenopausal Japanese women: a four-week study. - Journal of the American College of Nutrition 21(2): 97-102.

[23] USDA (2018): Oilseed: World Markets and Trade February, 2018. - USDA, Washington.

[24] Wang, J., Chen, P., Wang, D., Shannon, G., Zeng, A., Orazaly, M., Wu, C. (2015): Identification and mapping of stable QTL for protein content in soybean seeds. Molecular Breeding 35(3): 92.

[25] Xiao CW. (2008): Health effects of soy protein and isoflavones in humans. - Journal of Nutrition 138(6): 1244S-9S. 